\title{
An Investigation and Comparative Study of the Values of Young Teachers in Middle Schools
}

\author{
Anil Pshwar \\ Adv. N. S. Ganguwar College of Education, Gadchiroli, Maharashtra, India
}

\begin{abstract}
Education is intrinsically and by definition attitude oriented. Attitude and values are very important of life. The present study was conducted on secondary school teachers. The sample was taken from Gadchiroli district 100 teachers are selected.50 urban areas and 50 Rural areas. Attitude scale prepared by Dr. Umi Kulsum And value scale prepared by Dr. Harbhajan Singh. The obtained result indicate that no significant difference between Rural \& Urban secondary school teachers.
\end{abstract}

Keywords: Attitude, values, secondary school

\section{Introduction}

The attitude and values and outlook of the tribal arebeing appreciated by the contemporary Society. Values are defined in organizational behavior as the connective conception of what is considered good desirable \& proper or bad undesirable and Improper in a culture. Our values represent our personal guiding principles or life goals. Guiding our behavior in all aspects of life including our home life, our wok like, and our social life. The importance of values lies in their purpose, which is on short to guide our, beliefs, attitude and behaviors.

\section{Attitude:}

An attitude is someone between a belief, a stance, a mood and a pose. The definition of an attitude is a way of felling or acting toward a person, thing or situation. Passion for a sport, dislike for a certain actor and negativity toward life in general are each an example of an attitude not there are there types of attitude. Positive, negative and neutral.

Positive attitude: - This is one of attitude in organizational behavior.

Negative attitude: - A negative attitude is something that every person should avoid.

\section{Neutral attitude:}

Values:

Values are individual beliefs that motivate people to act one way or another. They serve as a guide for human behavior some values have intrinsic worth, Such as love, truth and freedom. Other values such as ambition, responsibility and courage describe trails or behavior are instrumental as means to an end.

\section{Objective}

1) To find out the significant difference in Attitude of Rural \&Urban secondary school teachers.

2) To find out the significant difference in Attitude of more \& female secondary school teachers.

3) To find out the significant difference in values of Rural $\&$ Urban secondary school teachers.

\section{Hypothesis}

1) To find out the significant difference in Attitude of Rural and Urban secondary school teachers.

2) There are no significant difference in attitude of male and female secondary school teachers.

3) There are no significant difference in value of Rural and Urban secondary school teachers.

4) There are no significant difference in values of male and female secondary school teachers.

\section{Sample}

100 secondary school teachers selected from Rural and Urban area located in Gadchiroli district.

\section{Tools Used in the Study}

Attitude Scale towards teaching profession created by Dr. Umi Kulsum \& Teachers value Inventory created by Dr. Harbhajan Singh \& Dr. S. P. Ahaluwalia.

\section{Data Analysis}

Differential analysis were used to compare the data and to verify the hypothesis by using statistics. The result of analysis are presented in table 1 to 4 .

Table 1: Significant difference in attitude of Rural \& Urban secondary school teachers

\begin{tabular}{|c|c|c|c|c|c|}
\hline Teacher & $\mathrm{N}$ & Mean & SD & t. Value & Significant Level \\
\hline Rural & 50 & 160.08 & 18.60 & \multirow{2}{*}{0.16} & \multirow{2}{*}{ Not Significant } \\
\hline Urban & 50 & 160.20 & 19.40 & & \\
\hline
\end{tabular}

Table 2: Significant difference in attitude of Male \& Female secondary school teachers

\begin{tabular}{|c|c|c|c|c|c|}
\hline Teacher & $\mathrm{N}$ & Mean & SD & t. Value & Significant Level \\
\hline Male & 50 & 160.04 & 18.35 & 0.14 & \multirow{2}{*}{ Not Significant } \\
\hline Female & 50 & 160.21 & 19.49 & 0.16 & \\
\hline
\end{tabular}

Table 3: Significant difference in Value of Rural \& Urban secondary school teachers

\begin{tabular}{|c|c|c|c|c|c|}
\hline Teacher & $\mathrm{N}$ & Mean & SD & t. Value & Significant Level \\
\hline Rural & 50 & 98.86 & 13.91 & 0.30 & \multirow{2}{*}{ Not Significant } \\
\hline Urban & 50 & 98.58 & 13.71 & 0.16 & \\
\hline
\end{tabular}

Table 4: Significant difference in Value of Male \& Female secondary school teachers

\begin{tabular}{|c|c|c|c|c|c|}
\hline Teacher & $\mathrm{N}$ & Mean & SD & t. Value & Significant Level \\
\cline { 1 - 4 } Male & 50 & 80.39 & 12.31 & \multirow{2}{*}{0.78} & \multirow{2}{*}{ Not Significant } \\
\hline Female & 50 & 82.02 & 11.88 & & \\
\hline
\end{tabular}




\section{Testing of Hypothesis}

From table 1: - Mean \& SD of Rural teachers are $160.08 / 18.60 \&$ Mean \& SD of Urban teachers are $160.20 / 19.40 \mathrm{~T}$ - value of both is 0.16 there are no significant difference in Attitude of Rural \& Urban secondary school teachers.

From table 2: - Mean \& SD of Male teachers are $160.04 / 1835 \&$ Mean \& SD of female teachers are $160.21 / 19.49 \mathrm{~T}$ - value of both is 0.14 there are no significant difference in 0.14 there are no significant difference in Attitude of Male \& Female secondary school teachers.

From table 3: - Mean \& SD of Rural teachers are 98.86/13.91 \& Mean \& SD of Urban teachers are 98.58/13.71 $\mathrm{T}$ - value of both is 0.30 there are no significant difference in value of Rural \& Urban teachers.

From table 4: - Mean \& SD of Male teachers are 80.39/12.31 \& Mean \& SD Female teachers are 82.02/11.88 $\mathrm{T}$ - value of both 0.78 there are no significant difference in value of male \& female teachers.

\section{Conclusion}

Both Attitude \& values are developed to Rural \& Urban Secondary school teachers \& no significant difference in Attitude of Rural \& Urban secondary school teachers and male \& female teachers also.

These are no significant difference in values of Ruraal \& Urban secondary school teachers and male \& female teachers also.

\section{References}

[1] Agrawal Y. P (1966) Research in Education Delhi Book Depot.

[2] Best John. W (1961) Research in education New Delhi Prentice Hall of India Pvt. ltd.

[3] Shaffer R. David (1996) Development psychology Childhood \& Adolescence An international Thomson Publishing Company.

[4] http://www.infolibrarian.com

[5] http://www.sgbau.ac.in

[6] http://www.doaj.org 